\title{
IMPLEMENTASI DYNAMIC INTELECTUAL LEARNING (DIL) SEBAGAI SALAH SATU ADAPTIVE LEARNING MODEL
}

\author{
Ni Ketut Suarni ${ }^{1}$, Gede Rasben Dantes ${ }^{2}$ \\ ${ }^{1}$ Jurusan Pendidikan Bimbingan Konseling, Fakultas IImu Pendidikan, \\ Universitas Pendidikan Ganesha, Singaraja, Indonesia \\ ${ }^{2}$ Jurusan Manajemen Informatika, Fakultas Teknik dan Kejuruan, \\ Universitas Pendidikan Ganesha, Singaraja, Indonesia \\ email: tut_arni@yahoo.com ${ }^{1}$; rasben_dantes@yahoo.com²
}

\begin{abstract}
Abstrak
Tujuan penelitian ini adalah untuk melakukan implementasi sistem Dynamic Intellectual Learning (DIL). DIL adalah pengembangan dari sistem e-learning yang memberikan keleluasaan kepada pengguna untuk mengakses materi-materi pembelajaran sesuai dengan kemampuan intelektual yang dimiliki. Implementasi sistem ini akan dilakukan pada mahasiswa Jurusan Pendidikan Guru Sekolah Dasar (PGSD) Universitas Pendidikan Ganesha dalam mata kuliah "Perkembangan Pendidikan Anak". Ada 44 mahasiswa yang terlibat dalam implementasi sistem ini. Hasil implementasi ini menunjukkan bahwa setiap mahasiswa memiliki kemampuan yang berbeda-beda untuk menguasai materi pembelajaran. Jumlah akses yang paling sedikit dilakukan untuk menguasai 14 materi yang terdapat dalam sistem DIL adalah 8 kali. Sedangkan jumlah akses yang paling banyak dilakukan adalah 23 kali. Hasil implementasi ini menunjukkan bahwa memberikan keleluasaan terhadap mahasiswa (peserta didik) untuk mengakses materi pembelajaran sesuai dengan kemampuannya sangat perlu dilakukan. Sehingga waktu yang tersisa dari 14 kali pertemuan tersebut bisa digunakan untuk aktivitas lainnya, seperti: pemberian tugas, diskusi kelompok, maupun praktek di lapangan. Hal inilah yang tidak diperoleh dalam pembelajaran konvensional.
\end{abstract}

Kata Kunci: Dynamic Intellectual Learning, e-Learning, Metode Pembelajaran Kolaboratif, Metode Pembelajaran Konservatif 


\begin{abstract}
Aim of this research is to implement the Dynamic Intellectual Learning (DIL) system. DIL is a development of e-learning system which provides users with easier access to teaching materials that meet their capabilities. The implementation of this system was conducted at Education for Elementary Teacher Department of Ganesha University in the "Development of Children Psychology" course. There are 44 students involved on implementation of this system as a subject of this research. The results of DIL implementation show that each student has a different capability to conceive a learning content. The least number of accesses made to all learning contents which is provided by the system is 8 times. Whereas, the number of access is the most widely performed 23 times. It indicates that provide the flexibility to learner in accessing the learning contents is needed. This has not been obtained in the conventional learning method.
\end{abstract}

Keywords: Dynamic Intellectual Learning, e-Learning, Collaborative Learning Method, Conservative Learning Method.

\section{PENDAHULUAN}

Berkembangnya

Teknologi Informasi dan Komunikasi (TIK), lembaga pendidikan diharapkan dapat memanfaatkan dan memberdayakan teknologi yang tersedia dalam mendukung proses belajar mengajar dan juga saling berbagi sumber daya (resource sharing). Bergesernya paradigma pembelajaran dari faculty teaching ke student-centered learning, memberikan keleluasaan kepada peserta didik untuk mengeksplorasi dirinya. Namun student-centered learning yang berkembang saat ini hanya terbatas pada content management system (CMS). Model Dynamic Intellectual Learning yang berorientasi pada prior-knowledge masingmasing peserta didik, diharapkan dapat melengkapi aplikasi-aplikasi e-learning yang berkembang saat ini.

$\begin{array}{cccc}\text { Sistem } & \text { Dynamic } & \text { Intellectual } \\ \text { Learning (DIL) akan memberikan }\end{array}$ kesempatan kepada pengguna (peserta didik) untuk mengakses materi perkuliahan sesuai dengan intelektual atau kemampuannya masing-masing. Sehingga peserta didik yang memiliki kemampuan lebih dibandingkan dengan yang lainnya akan memiliki kesempatan mengeksplorasi materi perkuliahan lebih banyak dan lebih cepat. Artinya bahwa masing-masing peserta didik tidak harus menghadapi materi yang sama. Sistem yang dikembangkan akan menganalisis secara serta merta kemampuan masing-masing pengguna. Hal ini tidak akan diperoleh pada metode pembelajaran konvensional (tatap muka di kelas), dimana peserta didik akan memperoleh perlakuan yang sama baik yang memiliki intelektual (kemampuan dasar) yang lebih baik maupun yang kurang. Model Dynamic Intellectual Learning merupakan pengembangan e-learning yang sudah banyak diterapkan di berbagai lembaga pendidikan formal maupun non formal. DIL ini berorientasi pada priorknowledge masing-masing peserta didik sehingga dapat diakses tanpa terbatas oleh waktu dan ruang, sehingga dapat memberikan kesempatan kepada pengguna untuk mengakses materi yang berbedabeda sesuai dengan kemampuan masingmasing.

Saat ini sudah banyak lembaga pendidikan mengkolaborasikan e-learning dengan metode pengajaran konvensional (tatap muka). Walaupun belum berjalan dengan optimal, namun beberapa pakar 
memperkirakan bahwa akan terjadi perubahaan paradigma pembelajaran dari faculty teaching menuju student centered learning.

Suatu hal yang perlu diperhatikan dalam impelementasi e-learning adalah sistem ini tidak hanya mampu mentransfer bahan ajar dari institusi pendidikan kepada mahasiswa, tetapi yang jauh lebih penting adalah bagaimana sistem ini mampu memfasilitasi interaksi yang terjadi baik antara mahasiswa dan pengajar maupun antar mahasiswa sendiri. Sehingga hal ini mampu menghadirkan suasana atau iklim akademik yang hidup dan dinamis dan mampu mencetak mahasiswa dengan kemampuan berpikir kritis dan analitis dalam memecahkan permasalahan.

\section{KAJIAN TEORI}

Pada bagian ini akan dibahas mengenai kajian teori tentang e-learning (pembelajaran secara online) dan juga sistem Dynamic Intellectual Learning (DIL) yang telah dikembangkan.

\subsection{Pembelajaran Secara Online (e- Learning)}

Pembelajaran menurut Dimyati dan Mudjiono (1999:297) adalah kegiatan guru secara terprogram dalam desain instruksional, untuk membuat siswa belajar secara aktif, yang menekankan pada penyedian sumber belajar. UUSPN No. 20 Tahun 2003 menyatakan pembelajaran adalah proses interaksi peserta didik dengan pendidik dan sumber belajar pada suatu lingkungan belajar. Pembelajaran sebagai proses belajar yang dibangun oleh guru untuk mengembangkan kreativitas berpikir yang dapat meningkatkan kemampuan berpikir siswa, serta dapat meningkatkan mengkonstruksikan pengetahuan baru sebagai upaya meningkatkan penguasaan yang baik terhadap materi pelajaran. (Sagala, 2005). Seiring dengan perkembangan teknologi sekarang ini metode pembelajaran yang konvensional telah berkembang menjadi e-learning.

Secara sederhana e-learning dapat diartikan sebagai pembelajaran elektronik. Beberapa istilah lain yang digunakan untuk e-learning adalah: internet-based learning (belajar berbasis internet), virtual learning (belajar melalui lingkungan maya), webbased learning (belajar berbasis web). Darin E. Hartley menyatakan e-learning merupakan suatu jenis belajar mengajar yang memungkinkan tersampaikannya bahan ajar ke siswa dengan menggunakan media internet, intranet, atau media jaringan komputer lain. LearnFrame.Com dalam Glossary of e-Learning Terms menyatakan suatu definisi yang lebih luas bahwa $e$ learning adalah sistem pendidikan yang menggunakan aplikasi elektronik untuk mendukung belajar mengajar dengan media internet, jaringan komputer, maupun komputer standalone. (Romi, 2005). Beberapa ahli mengemukakan bahwa istilah e-learning mengacu pada penggunaan teknologi internet untuk menyajikan sejumlah pilihan solusi yang sangat luas (a broad array of solution) yang mengarah pada peningkatan pengetahuan dan performance. Struktur umum e-learning pada dasarnya adalah sebagai berikut .

Keunggulan e-learning sebagai salah satu alternatif paradigma pendidikan melalui internet (Kardiawarman, 2000) adalah sebagai berikut.

1) paradigma virtual teacher resources, yang dapat mengatasi terbatasnya jumlah guru yang berkualitas, sehingga siswa tidak harus secara 
intensif memerlukan dukungan guru, karena peranan guru maya (virtual teacher) dan sebagian besar diambil alih oleh sistem belajar tersebut.

2) virtual school system, yang dapat membuka peluang menyelenggarakan pendidikan dasar, menengah dan tinggi yang tidak memerlukan ruang dan waktu. Keunggulan paradigma ini daya tampung siswa tak terbatas. Siswa dapat melakukan kegiatan belajar kapan saja, dimana saja, dan darimana saja.

3) paradigma cyber educational resources system, atau dot com $\begin{array}{lrr}\text { learning } & \text { resources } & \text { system. } \\ \text { Merupakan } & \text { pedukung } & \text { kedua }\end{array}$ paradigma di atas, dalam membantu akses terhadap artikel atau jurnal elektronik yang tersedia secara bebas dan gratis dalam internet.

Namun sebagai salah satu alternatif paradigma pendidikan, e-learning memiliki kelemahan yaitu tidak dapat membedakan kemampuan dasar (intelektual) setiap peserta didik. Artinya bahwa, setiap peserta didik dapat mengakses materi yang sama atau setiap peserta didik mendapat perlakuan yang sama dalam proses belajar mengajar.

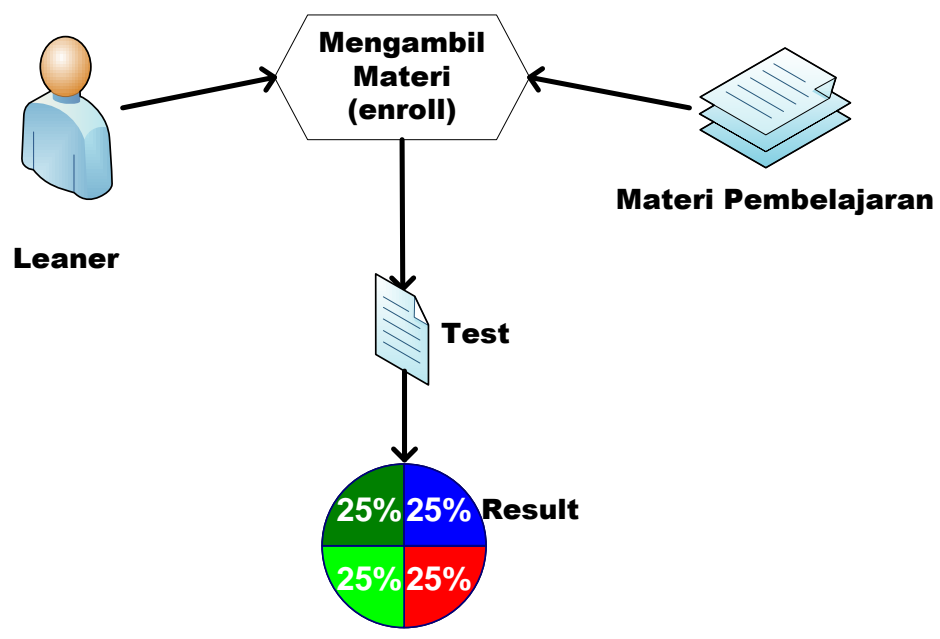

Gambar 1. Struktur Umum e-Learning

\subsection{Sistem Dynamic Intellectual Learning (DIL)}

Dynamic Intellectual Learning (DIL) merupakan pengembangan e-learning yang saat ini sudah banyak diimplementasi di beberapa lembaga pendidikan baik formal maupun informal. Model DIL akan memberikan kesempatan kepada para peserta didik untuk mengeksplorasi materi perkuliahan sesuai dengan kemampuan masing-masing peserta didik. Implementasi e-learning pada umumnya, tidak melakukan pembedaan pada peserta didik, setiap peserta didik dapat mengakses materi tanpa mempertimbangkan kemampuan dasar (intelektual) yang dimiliki. Adapun langkah- 
langkah yang dilakukan dalam metode DIL sebagai berikut (Dantes, dkk., 2010)..

1. Melakukan uji coba pre-tes terhadap peserta didik

Sebelum mengambil bab (chapter) dari sebuah materi (course) peserta didik akan memperoleh pre-tes dengan ketentuan sebagai berikut.

a. Soal yang diambil adalah beberapa soal yang mewakili masing-masing bab dalam materi tersebut.

b. Soal diambil sebanyak $20 \%$ dari soal yang akan dikeluarkan nanti pada tes session.

c. Hasil yang dipakai adalah lulus atau tidak peserta didik pada sebuah bab.

d. Hasil lulus atau tidak pada sebuah bab ditentukan dengan persentase jumlah jawaban yang benar pada soal di bab tersebut dengan jumlah soal yang diambil pada bab tersebut lebih dari $66 \%$.

Tujuan adanya pre-tes ini adalah untuk mengetahui kemampuan awal dari peserta didik. Setelah melakukan pengujian pre-tes, sistem akan memberikan bab yang berhak untuk diakses pada materi sesuai tingkat pemahaman peserta didik. Kemungkinan yang bisa diperoleh dari hasil pre-tes tersebut adalah sebagai berikut.

a) Tidak ada bab yang lulus

Jika semua bab tidak lulus maka peserta didik hanya boleh mengakses bab terendah yang belum lulus dan tidak terkunci.

b) Beberapa bab lulus atau semua bab lulus

Jika ada beberapa atau semua bab yang lulus maka yang dapat diakses adalah bab yang lulus saja.

2. Memilih materi

Peserta didik boleh memilih materi yang telah diposting. Sistem akan mengecek apakah ada bab yang harus diambil pada materi atau tidak. Kemungkinan kejadian adalah:

a) Ada bab yang harus diambil Ini adalah kondisi dimana peserta didik sudah pernah melakukan pembelajaran sebelumnya namun ada bab yang tidak lulus sehingga bab tersebut harus dituntaskan sebelum melanjutkan pembelajaran. Peserta didik akan langsung dibawa untuk mengambil bab.

b) Tidak ada bab yang harus diambil Kemungkinan dari kondisi ini adalah peserta didik belum pernah mengambil pembelajaran pada materi atau sudah pernah melakukan pembelajaran dengan hasil semua bab lulus. Peserta didik selanjutnya dibawa untuk mengambil pre- tes.

3. Mengambil bab

Ada 2 kondisi dalam pengambilan materi

a. Kondisi dimana peserta didik bebas dalam memilih materi

b. Kondisi dimana peserta didik harus mengambil materi yang ditentukan. Ini terjadi karena ada materi yang tidak lulus pada session tes sehingga harus dituntaskan.

4. Mengambil session tes

Setelah memilih bab yang diberikan dari langkah 3 di atas peserta didik diharuskan untuk mengambil session tes. Adapun ketentuan dari session tes adalah sebagai berikut. 
a) Soal yang diambil dari session tes adalah soal dari bab yang diambil, beserta soal dari bab relasi yang telah ditentukan oleh pemosting.

b) Hasil lulus atau tidak pada sebuah bab ketentuannya sama dengan soal pada pre-tes, perbedaannya yaitu batas kelulusan ditentukan pemosting saat menentukan relasi.

c) Jika peserta didik tidak mengambil session tes, peserta didik tidak akan bisa melanjutkan pembelajaran.

d) Hasil yang diperoleh nanti berupa lulus atau tidak peserta didik pada masing masing bab.

Kemungkinan yang bisa diperoleh dari hasil tes session ini adalah adalah sebagai berikut.

a) Peserta didik lulus di semua bab Jika peserta didik lulus di semua bab maka peserta didik boleh melanjutkan pembelajaran untuk mengambil bab lain.

b) Ada beberapa bab yang tidak lulus atau semua bab tidak lulus.

Jika ada bab yang tidak lulus atau semua bab tidak lulus maka peserta didik akan diarahkan untuk mengambil bab terkecil yang tidak lulus. Semua bab yang berada di bawah bab terkecil yang tidak lulus tersebut akan diluluskan, sedangkan untuk bab yang berada di atas bab terkecil yang tidak lulus yang memilki hubungan dengan bab tersebut untuk sementara aksesnya ditutup.

5. Peserta didik diharuskan mengambil materi yang tidak lulus

Kejadian ini akan terjadi dimana peserta didik diharuskan untuk mengambil bab terkecil yang belum lulus saat session tes. Kemungkinan hasil yang didapat adalah:

a) Peserta didik lulus di bab tersebut Peserta didik boleh melanjutkan pembelajaran untuk bab yang lain.

b) Peserta didik tidak lulus di materi tersebut

Peserta didik hanya diberikan kesempatan untuk mengulang session sebanyak 3 kali. Jika lebih dari itu peserta didik belum lulus maka peserta didik tidak boleh lagi mengambil bab tersebut dan juga tidak boleh mengambil bab yang berhubungan dengan bab yang tidak lulus tersebut. Dengan kata lain bab pada materi tersebut akan dikunci.

Alur aktivitas learner sesuai langkah di atas dalam Dynamic Intellectual Learning dapat di gambarkan sebagai berikut. 


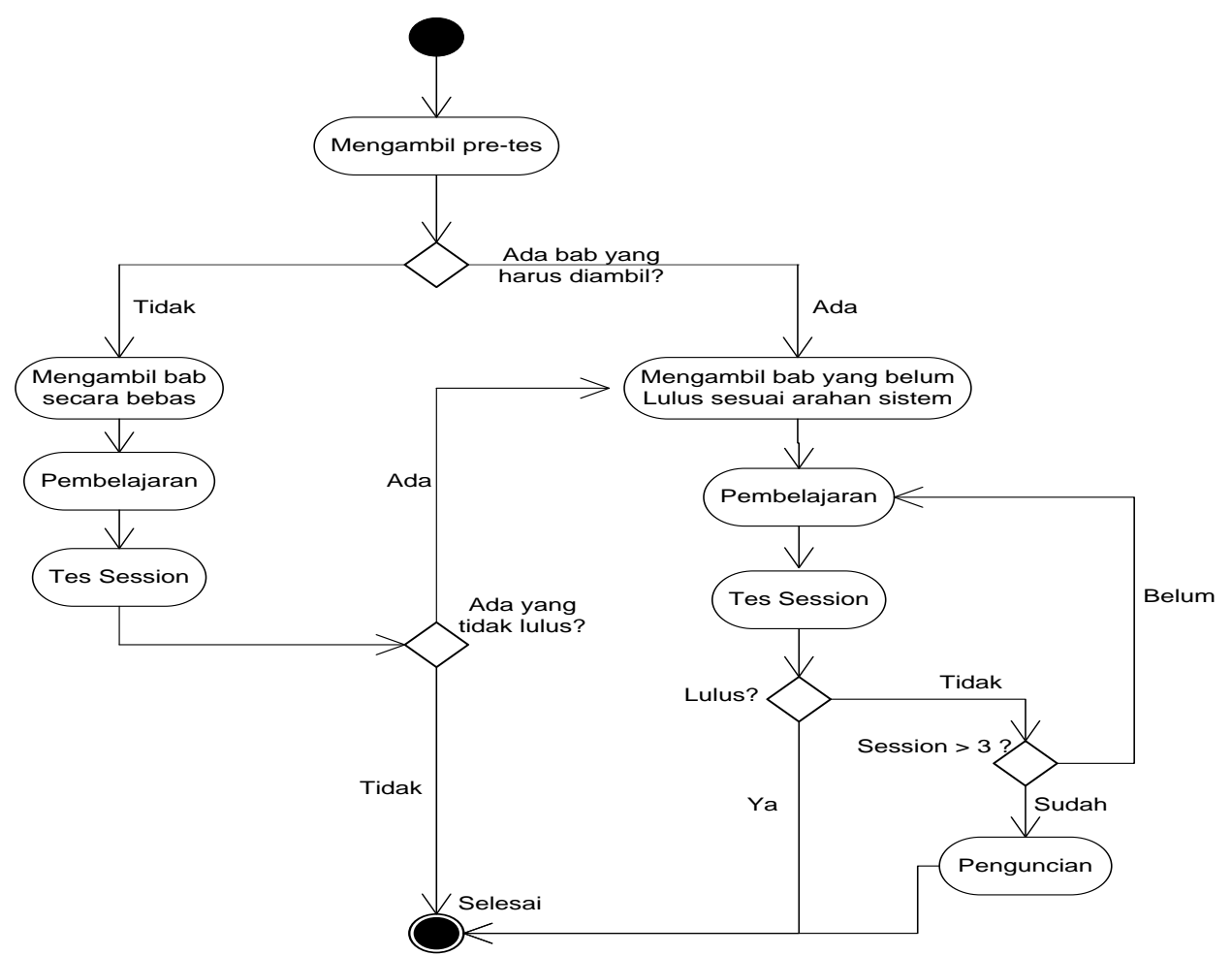

Gambar 2. Aliran Aktivitas Dynamic Intellectual Learning

Dari langkah-langkah dalam DIL di atas yang sangat berperan penting adalah akses user terhadap bab pada suatu materi, yaitu:

1. Tertutup

Artinya bahwa bab tersebut tidak bisa di akses oleh user. Ini merupakan setingan awal dimana user belum pernah mengambil bab dalam materi manapun. Akses tertutup ini akan menjadi terbuka jika user learner lulus pada bab saat mengambil pre tes. Pada intinya akses tertutup masih bisa mengalami perubahan setelah pengambilan pre tes.

2. Terbuka

Artinya bahwa bab tersebut bisa di akses oleh user. Ini bisa terjadi setelah user learner telah mengambil pre tes dimana bab yang lulus aksesnya akan terbuka, sedangkan bab yang tidak lulus aksesnya masih tertutup.

3. Terbuka dan harus diambil

Artinya bahwa bab tersebut diharuskan untuk diambil sebelum melanjutkan untuk mempelajari bab yang lainnya. Jadi ketika user learner mengakses materi maka user learner akan langsung menuju pengambilan bab tanpa melalui pre tes. Akses ini di dapatkan ketika user learner sudah pernah melakukan pembelajaran. Setelah melakukan tes jika hasilnya ada bab yang tidak lulus maka untuk bab terkecil yang tidak lulus aksesnya 
akan menjadi terbuka dan harus di ambil.

4. Terkunci

Artinya bab tersebut sudah tidak bisa di akses lagi kecuali di aktifkan kembali oleh pemosting yang bersangkutan. Jadi akses terkunci tidak akan bisa mengalami perubahan kecuali di ubah oleh pemosting.

Adapun struktur umum Dynamic Intellectual Learning yang membedakannya dengan elearning pada umumnya adalah adalah sebagai berikut .

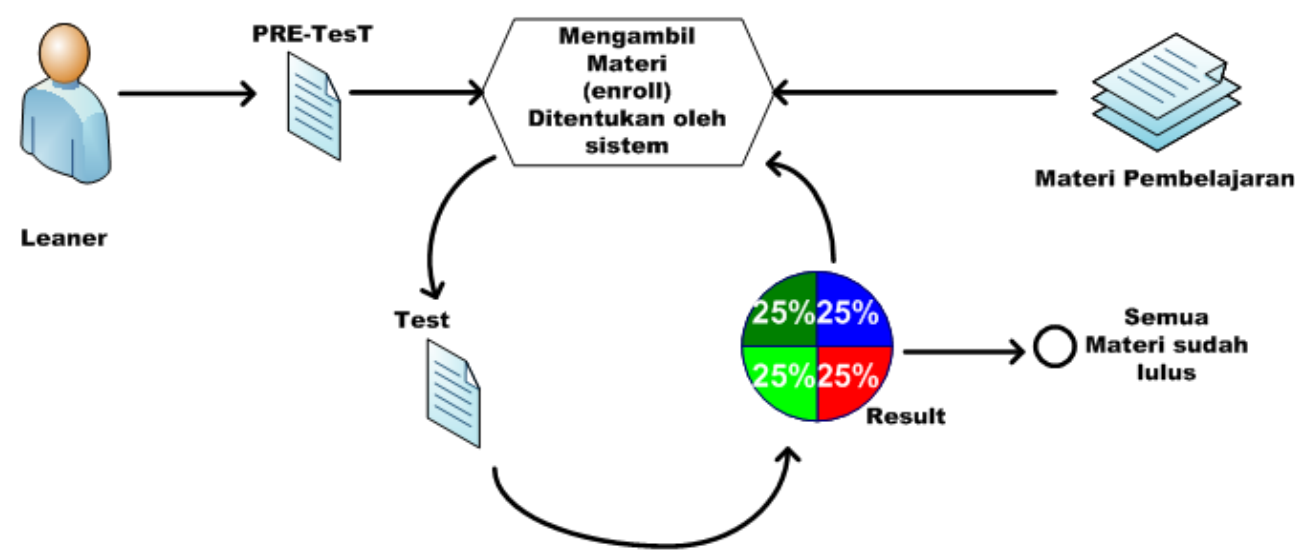

Gambar 3. Struktur Umum Dynamic Intellectual Learning (DIL)

\section{METODOLOGI}

Penelitian ini menggunakan desain penelitian pengembangan tipe "Prototipycal Studies" sebagaimana yang dikedepankan oleh Akker (1999) dan Plomp (2001). Hal penting yang perlu diperhatikan dalam penelitian pengembangan adalah kualitas model pembelajaran (DIL berbasis ICT) atau produk yang dihasilkan. Populasi penelitian adalah dosen dan mahasiswa di lingkungan Universitas Pendidikan Ganesha, khususnya mahasiswa Jurusan Pendidikan Guru Sekolah Dasar (PGSD) dan dosen Jurusan Bimbingan Konseling (BK) yang akan digunakan sebagai pilot project dalam pengembangan model ini.

Dalam pengembangan prototype Dynamic Intellectual Learning digunakan prototyping methodology yang merupakan salah satu software development methodology, yang terdiri dari 5 tahapan: system requirement, system analysis \& design, prototyping (pengembangan model), evaluation (testing) dan implementation. Sedangkan instrumen yang digunakan dalam model ini dilakukan validasi awal dengan menggunakan uji butir untuk melihat tingkat reliabilitas dan tingkat kesukaran dari instrumen yang dikembangkan. Namun perlu dilakukan validasi lebih lanjut terhadap instrumen yang digunakan baik secara empirik maupun expert judgement dan evaluasi model dalam penelitian pada tahap berikutnya.

Pada penelitian saat ini difokuskan pada implementasi sistem DIL yang 
mengacu pada penelitian sebelumnya. Ada tiga hal penting yang dilakukan pada penelitian ini, yaitu: (1) redesign sistem DIL, (2) pengembangan konten pembelajaran yang lebih menarik, dan (3) implementasi sistem DIL dalam perkuliahan. Dalam implementasi sistem DIL, matakuliah "Perkembangan Pendidikan Anak" di Jurusan Pendidikan Guru Sekolah Dasar, Universitas Pendidikan Ganesha digunakan sebagai pilot study. Ada 44 mahasiswa yang terlibat dalam implementasi sistem ini. Histori pembelajaran dari masing-masing mahasiswa dalam menggunakan sistem DIL akan direkam oleh sistem. Implementasi sistem DIL ini dilakukan mulai bulan Agustus sampai dengan Oktober 2011. Dari data yang diperoleh akan dilakukan analisis statistik deskriptif dengan menampilkan grafik-garfik yang menggabarkan hasil implementasi sistem yang dapat digunakan sebagai salah satu indikator untuk mengetahui keberhasilan dari sistem yang dikembangkan.

\section{HASIL \& PEMBAHASAN}

Pada bagian ini akan dibahas pengembangan konten pembelajaran dan implementasi sistem DIL.

\subsection{Redesign Sistem Dynamic Intellectual Learning}

Dari hasil uji coba model yang sudah dilakukan pada penelitian sebelumnya, ada beberapa perbaikan dari sisi sistem, konten pembelajaran maupun evaluasi. Perbaikan dari sistem banyak dilakukan untuk memperbaiki kinerja sistem (system performance) dan tampilan antar muka (user interface). Sedangkan dari sisi konten pembelajaran, dikembangkan konten yang lebih menarik untuk memotivasi peserta didik untuk mengakses konten pembelajaran yang disediakan. Konten pembelajaran yang dikembangkan dibahas lebih detil pada subbab berikutnya. Dari sisi evaluasi, dilakukan beberapa perubahan pada soal-soal evaluasi yang digunakan untuk menilai pemahaman peserta didik tentang materi yang dipelajari. Setelah dilakukan validasi terhadap instrumen yang digunakan dalam model ini diperoleh bahwa dari 60 butir diujikan dinyatakan gugur 23 butir dengan $\mathrm{N}=43$, tingkat reliabilitas $0,82 \%$ dan tingkat kesukaran dengan rincian: mudah $40,25 \%$, sedang $32 \%$, sukar $27,75 \%$.

\subsection{Pengembangan Pembelajaran}

Konten

Pada penelitian tahun ketiga ini dikembangkan konten pembelajaran yang lebih menarik. Hal ini diharapkan dapat meningkatkan minat dan motivasi peserta didik untuk mengakses materi-materi pembelajaran yang sudah dikembangkan sebelumnya. Pada konten pembelajaran yang dikembangkan ini terdiri dari 3 menu utama, yaitu: lihat materi, video, dan evaluasi. Matakuliah yang digunakan sebagai uji coba dalam penelitian ini, terdiri dari 4 bab yang dibagi ke dalam 14 pertemuan. Masing-masing bab akan terdiri dari evaluasi untuk mengetahui pemahaman peserta didik terhadap materi yang diakses. Gambar di bawah menunjukkan halaman depan konten pembelajaran, dimana mahasiswa harus login sebelum dapat mengakses materi-materi yang disediakan. 


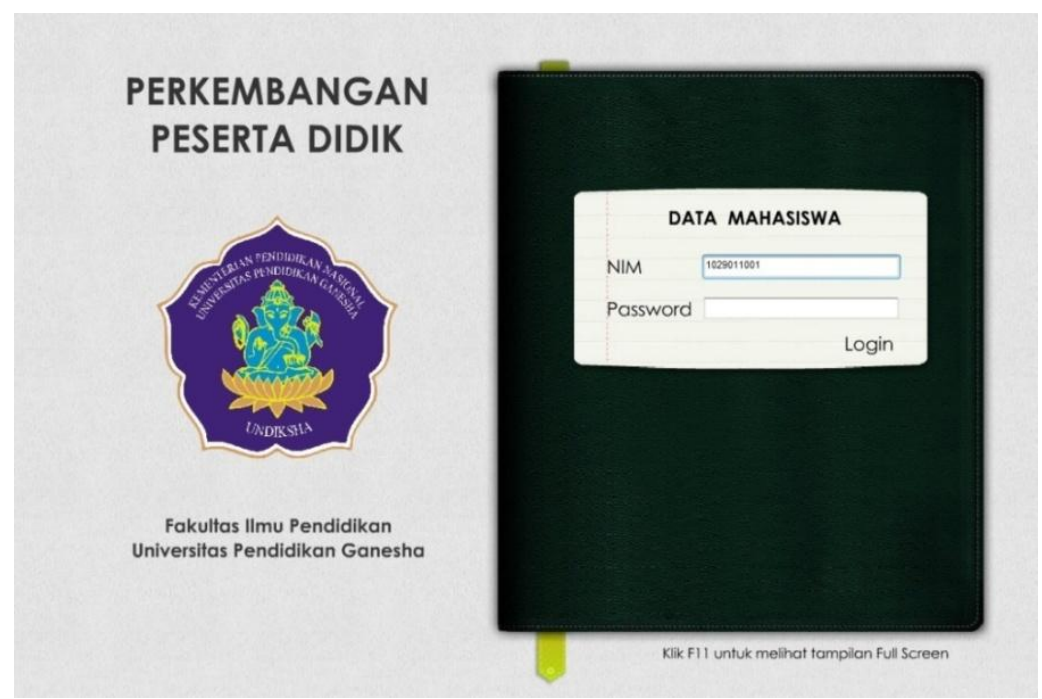

Gambar 4. Halaman Utama Konten Pembelajaran

Pada halaman materi akan ditampilkan pokok bahasan, sub pokok bahasan dan kompetensi dasar dari masingmasing materi yang akan dibahas. Hal ini bertujuan untuk memberikan gambaran

secara menyeluruh tentang materi-materi yang akan dibahas. Sehingga mahasiswa diharapkan dapat mengambil sari dari materi yang disajikan sesuai dengan kompetensi dasar yang ingin dicapai.

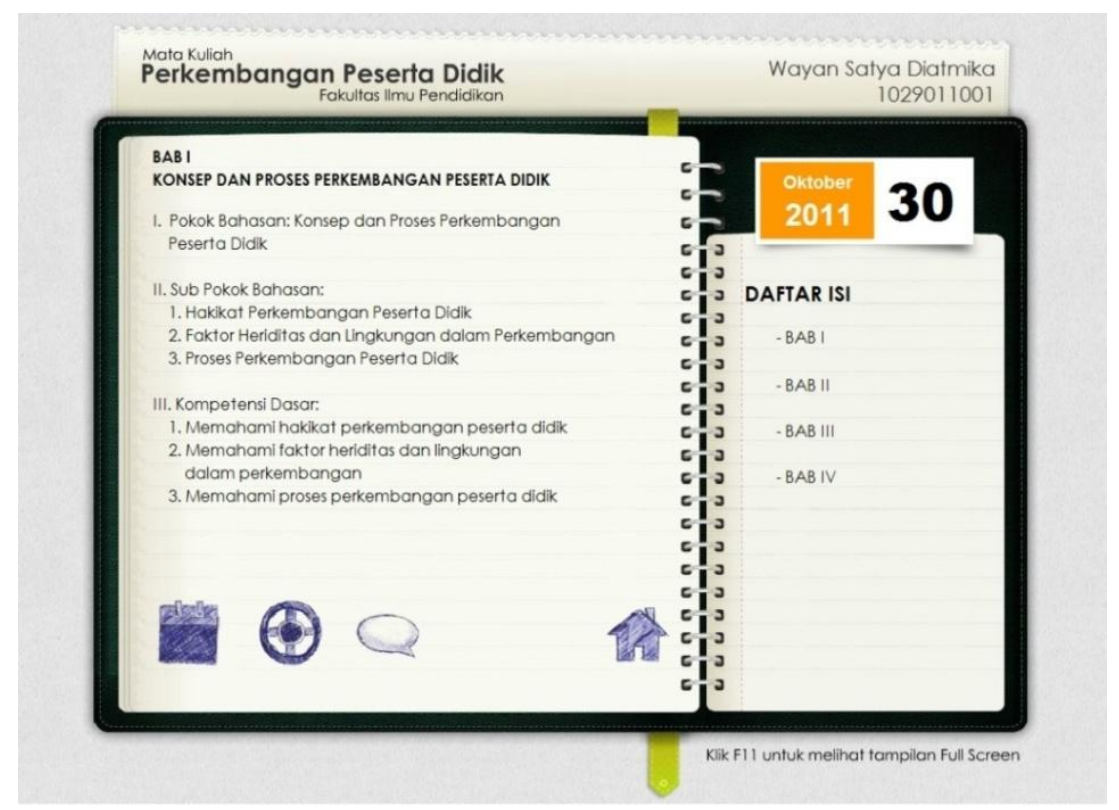

Gambar 5. Halaman Materi Perkembangan Peserta Didik 
Pada konten pembelajaran ini juga ditampilkan beberapa video yang terkait dengan materi pembelajaran. Hal ini diharapkan dapat memberikan gambaran yang lebih jelas tentang materi yang dipelajari. Pada gambar di bawah terlihat ada dua contoh video yang menjelaskan tentang pembuahan pada manusia dan juga gens pada manusia.

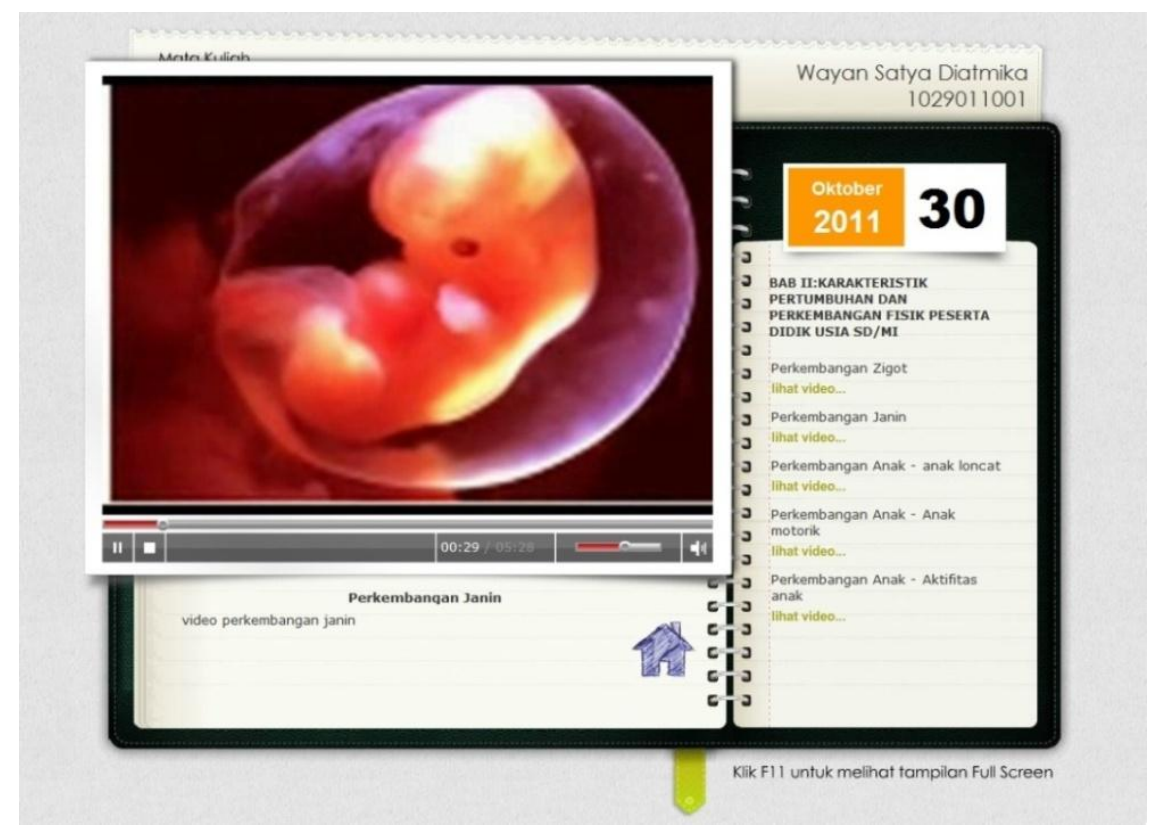

Gambar 6. Tampilan dalam bentuk video pada konten pembelajaran

Video-video maupun materi-materi yang disajikan dalam konten pembelajaran ini akan dikelola oleh admin/dosen/pendidik. Sehingga materi-materi maupun video-video selalu terupdate sesuai dengan kebutuhannya. Sedangkan mahasiswa tidak diijinkan untuk masuk ke halaman admin ini.

\begin{tabular}{|c|c|c|c|c|c|}
\hline \multirow{2}{*}{$\log :$ admin } & \multicolumn{4}{|c|}{ VIDEO MATERI } & \multirow{2}{*}{$\begin{array}{l}\text { Total : } \\
\text { BAB }\end{array}$} \\
\hline & ID & JUDUL & KETERANGAN & NAMA FILE & \\
\hline \multirow{5}{*}{$\begin{array}{l}\text { X Logout } \\
\text { View Home Page } \\
\text { index } \\
\text { Operator }\end{array}$} & $\square 1$ & Pembuahan pada manusia & Video tentang pembuahan pada manusia & Perkembangan Zigot Edit.flv & 1 \\
\hline & $\square 3$ & Gens pada manusia & Video gens pada manusia & video3.fiv & 1 \\
\hline & $\square 4$ & Perkembangan Zigot & Video Perkembangan zigot & Perkembangan Zigot Edit1.flv & 2 \\
\hline & $\square 5$ & Perkembangan Janin & video perkembangan janin & video.flv & 2 \\
\hline & $\square 6$ & Perkembangan Anak - anak loncat & video anak locat & anak loncat. flv & 2 \\
\hline \multirow{7}{*}{$\begin{array}{l}\text { > MAHA SISWA } \\
>\text { MATERI } \\
\text { > VIDEO MATERI } \\
>\text { SOAL EVALUASI } \\
\text { > STATISTIK EVALUASI }\end{array}$} & $\square 7$ & Perkembangan Anak - Anak motorik & video anakk motorik & anak motorik.flv & 2 \\
\hline & 88 & Perkembangan Anak - Aktiftas anak & video Perkembangan Anak - Aktiftas anak & chil aktivity.flv & 2 \\
\hline & $\square 9$ & Anak dengan kemapuan Bahasa Luar Biasa & video Anak dengan kemapuan Bahasa Luar Biasa & anak jenius. flv & 3 \\
\hline & 10 & \multicolumn{2}{|c|}{ Pendidikan Untuk Anak Yang Berkebutuhan Khusus video Pendidikan Untuk Anak Yang Berkebutuhan Khusus } & pendidikan.flv & 4 \\
\hline & \multicolumn{5}{|c|}{ HAPUS DATA YANG ANDA PILIH ] [ KLIK ID UNTUK EDIT/UPDATE ] } \\
\hline & \multicolumn{5}{|l|}{$\begin{array}{l}\text { Page: } \\
\text { [1] }\end{array}$} \\
\hline & \multicolumn{5}{|c|}{ TAMBAH BARU } \\
\hline
\end{tabular}

Gambar 7. Halaman admin untuk mengelola materi video 


\subsection{Implementasi Sistem Dynamic Intellectual Learning}

Sistem Dynamic Intellectual Learning (DIL) sudah digunakan dalam matakuliah "Perkembangan Psikologi Anak" pada jurusan PGSD Universitas Pendidikan Ganesha. Implementasi sistem DIL ini dilakukan dari bulan agustus sampai oktober 2011 (data histori hasil pembelajaran dengan sistem DIL terlampir). Jumlah mahasiswa yang terlibat dalam implementasi sistem DIL ini sebanyak 44 orang yang mengambil matakuliah "Perkembangan Psikologi Anak". Dari 44 orang mahasiswa yang mengambil matakuliah ini, 5 orang dinyatakan tidak lulus dan 39 orang lulus. Metode pembelajaran yang diterapkan pada penelitian ini adalah kolaboratif dengan memadukan pembelajaran tatap muka dan pembelajaran online dengan memanfaatkan sistem DIL. Mahasiswa dinyatakan lulus, apabila sudah mengambil seluruh materi (14 materi yang tersedia) dan lulus dalam evaluasi sesuai dengan standar kelulusan yang ditentukan pada masing-masing materi..

\section{Hasil Implementasi Sistem DIL}

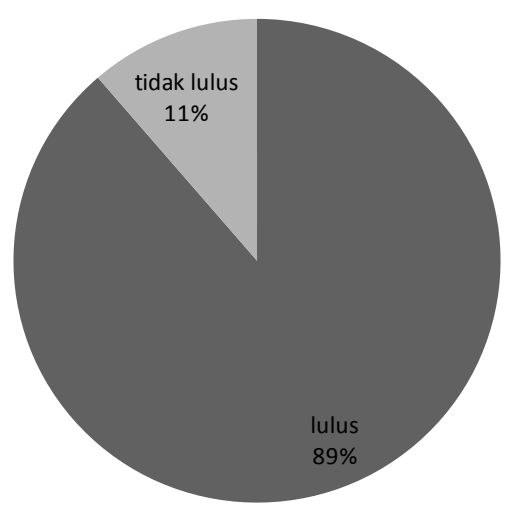

\section{Gambar 8. Grafik Hasil Implementasi Sistem DIL} (Agustus - Oktober 2011)

Dari 5 orang yang tidak lulus, memiliki pencapaian yang berbeda-beda, yaitu: 1 orang berhenti pada bab 1, 1 orang berhenti pada bab 5, 2 orang berhenti pada bab 7, dan 1 orang berhenti pada bab 9 . 


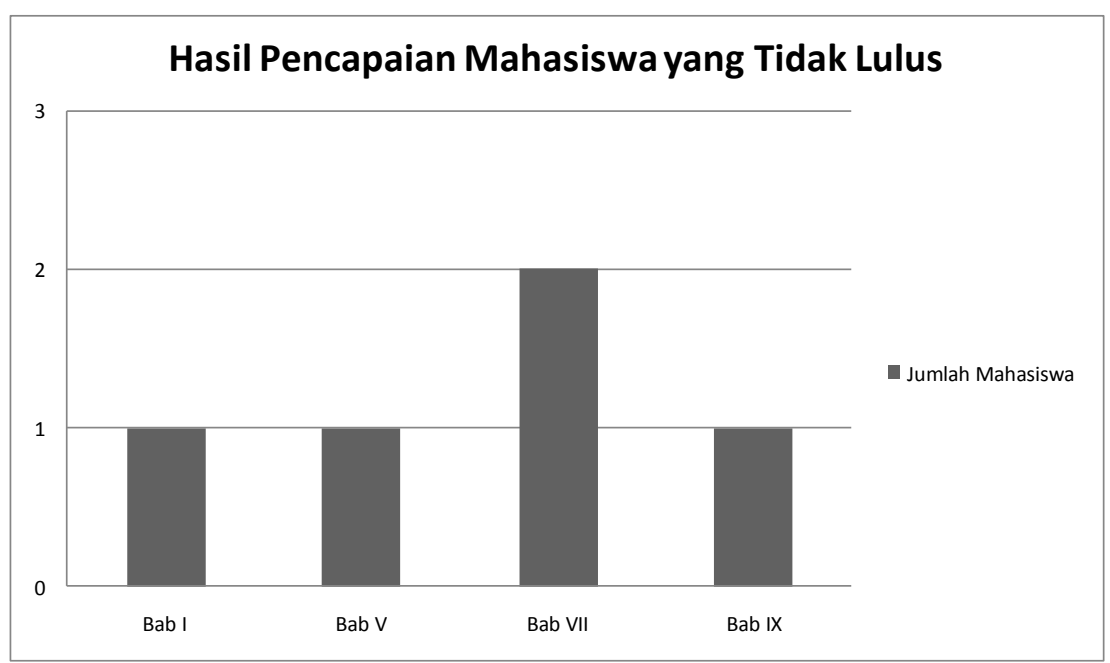

Gambar 9. Hasil pencapaian bagi mahasiswa yang tidak lulus

Untuk mahasiswa yang sudah lulus dari ke-14 materi yang disajikan, jumlah akses yang dilakukan berbeda-beda (seperti terlihat pada tabel 1). Jumlah akses yang dilakukan terhadap sistem DIL dapat digunakan sebagai salah satu indikator untuk melihat seberapa cepat mahasiswa menguasai materi-materi yang disajikan. $\mathrm{P}$ ada implementasi sistem DIL ini, terlihat bahwa rata-rata mahasiswa mengakses sistem DIL untuk dapat menguasai seluruh materi yang tersedia sebanyak 17 kali (ratarata $=16,62)$. Dari tabel di bawah terlihat bahwa hanya 1 mahasiswa yang dapat menguasai keseluruhan materi dengan 8 kali akses, dan hanya 1 mahasiswa yang mengakses sistem DIL paling banyak (23 kali).

Tabel 1. Jumlah Akses Sistem DIL dalam Penguasaan Seluruh Materi

\begin{tabular}{|c|c|c|c|c|}
\hline No. & $\begin{array}{c}\text { Jumlah Akses } \\
\text { Sistem DIL }\end{array}$ & $\begin{array}{c}\text { Jumlah } \\
\text { Mahasiswa }\end{array}$ & Persentase & Keterangan \\
\hline 1. & 8 kali & 1 & $2,56 \%$ & Lulus \\
\hline 2. & 10 kali & 1 & $2,56 \%$ & Lulus \\
\hline 3. & 13 kali & 3 & $7,69 \%$ & Lulus \\
\hline 4. & 14 kali & 5 & $12,82 \%$ & Lulus \\
\hline 5. & 15 kali & 5 & $12,82 \%$ & Lulus \\
\hline 6. & 16 kali & 5 & $12,82 \%$ & Lulus \\
\hline 7. & 17 kali & 4 & $10,26 \%$ & Lulus \\
\hline 8. & 18 kali & 1 & $2,56 \%$ & Lulus \\
\hline 9. & 19 kali & 5 & $12,82 \%$ & Lulus \\
\hline 10. & 20 kali & 4 & $10,26 \%$ & Lulus \\
\hline 11. & 21 kali & 3 & $7,69 \%$ & Lulus \\
\hline 12. & 22 kali & 1 & $2,56 \%$ & Lulus \\
\hline 13. & 23 kali & 1 & $2,56 \%$ & Lulus \\
\hline
\end{tabular}


Untuk lebih jelasnya, tabel di atas digambarkan dalam bentuk grafik di bawah ini.

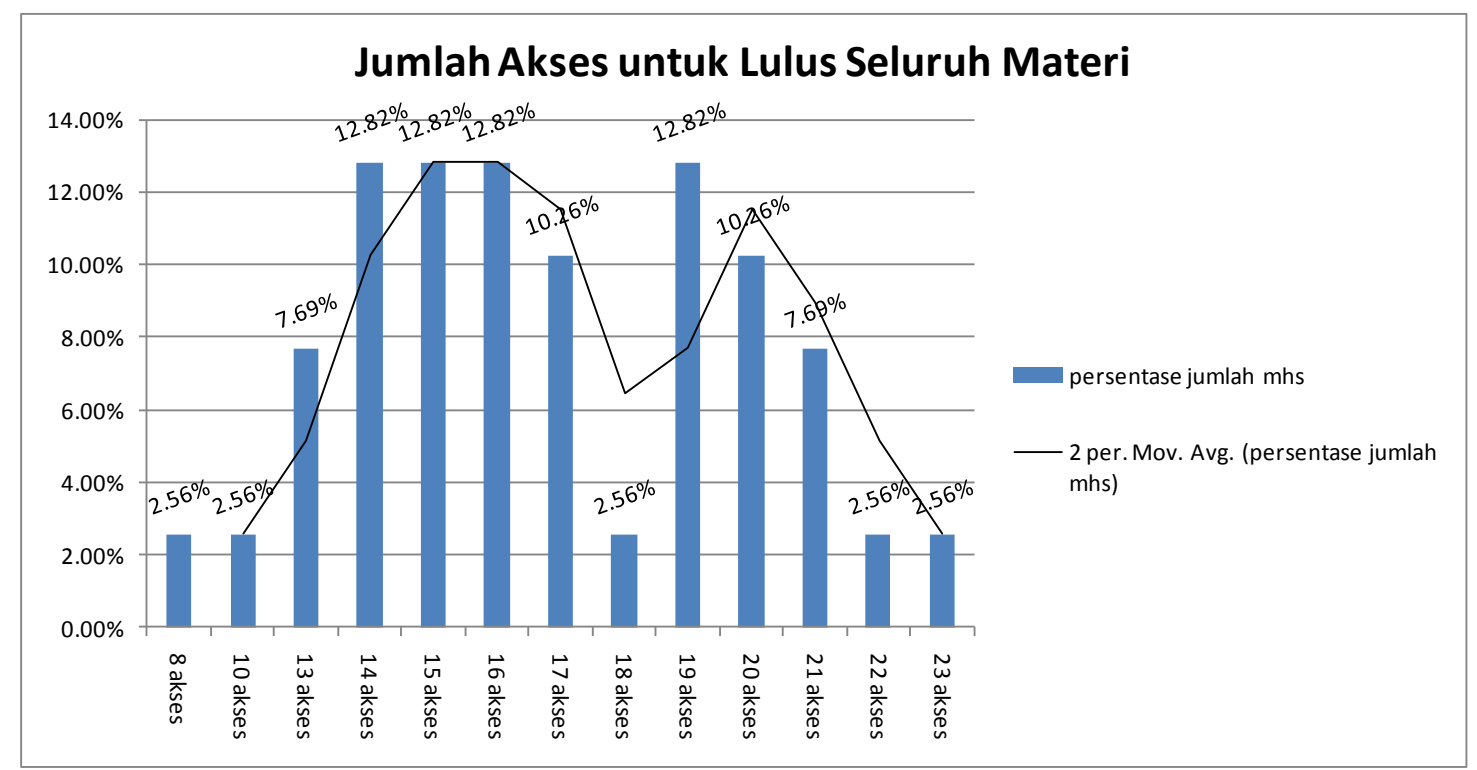

Gambar 10. Jumlah akses yang dilakukan mahasiswa untuk menguasai keseluruhan materi pembelajaran

\section{SIMPULAN}

Dari pembahasan di atas dapat disimpulkan bahwa 44 mahasiswa yang ikut terlibat dalam implementasi sistem DIL, sebanyak 39 orang (88,64\%) yang menyelesaikan keseluruhan materi (14 materi perkuliahan) dan 5 orang $(11,36 \%)$ tidak dapat menyelesaikan kesuluruhan materi. Masing-masing mahasiswa memiliki tingkat kecepatan pemahaman materi yang berbeda-beda. Dari 39 mahasiswa yang menyelesaikan keseluruhan materi, hanya 1 mahasiswa yang dapat mengakses sistem DIL sebanyak 8 kali untuk menyelesaikan seluruh materi. Sedangkan 1 mahasiswa sampai mengakses sebanyak 23 kali. Ratarata pengaksesan sistem DIL untuk menyelesaikan 14 materi yang disediakan sebanyak 17 kali (rata-rata $=16,62$ ) . Bagi mahasiswa yang tidak lulus, juga memiliki tingkat pemahaman yang berbeda-beda.
Dari 5 mahasiswa yang tidak lulus, 1 orang hanya sampai pada materi ke-1, 1 orang pada materi ke-5, 2 orang pada materi ke-7, dan 1 orang hanya sampai pada materi ke9.

Dari hasil implementasi sistem DIL ini menunjukkan bahwa untuk menyampaikan 14 materi dalam matakuliah ini tidak memelukan 14 kali pertemuan tatap muka. Kalo dilihat dalam kalender akademik, 14 materi dalam perkuliahan ini memerlukan waktu 14 minggu (3,5 bulan). Melalui sistem DIL ini, mahasiswa lebih cepat dapat mempelajari dan memahami seluruh materi yang seharusnya disampaikan secara tatap muka sebanyak 14 kali. Implementasi sistem DIL ini dilakukan dari bulan agustus-oktober. Namun rata-rata jumlah akses yang dilakukan oleh mahasiswa untuk menguasai keseluruhan materi sebanyak 16 kali. Ada juga mahasiswa hanya membutuhkan 8 kali 
akses untuk memahami 14 materi yang disediakan. Tetapi ada juga mahasiswa yang membutuhkan 23 kali akses untuk memahami keseluruhan materi. Hal ini menunjukkan bahwa memberikan keleluasaan terhadap mahasiswa (peserta didik) untuk mengakses materi pembelajaran sesuai dengan kemampuannya sangat perlu dilakukan. Hal inilah yang tidak diperoleh dalam pembelajaran konvensional. Sehingga waktu yang tersisa dari 14 kali pertemuan tersebut bias digunakan untuk aktivitas lainnya, seperti: pemberian tugas, diskusi kelompok, maupun praktek di lapangan.

\section{DAFTAR PUSTAKA}

Aziz M Farid. 2001. Belajar Sendiri Pemrograman PHP 4. Jakarta: Elex Media Komputindo.

Brown, Mary Daniels. 2000. Virtual High Schools, Part 1, The Voices of Experiences. http://www.educationworld.com/a tech/tech052.shtml, diakses tanggal: 8 Agustus 2007.

Conlan, O., Wade, V., Bruen, C. and Gargan, W., "Multi-model, metadata driven approach to adaptive hypermedia services for personalized eLearning",Adaptive Hypermedia and Adaptive Web-Based Systems: Second International Conference, $\mathrm{AH}$ 2002.

Dantes, G.R., Suarni, K, dan Sujaya, G., Model Dynamic Intellectual Learning (DIL): Pergeseran Paradigma Pembelajaran eLearning Menuju Adaptive Learning, Seminar Nasional STIKOM Bali, 2010.

Dunn, R., Dunn, K,\& Freely, M.E . Practical application of the Research: Responding to students' learning styles-step one. Ilinois State Research and Development Journal,1984

Fathansyah. 1999. Basis Data. Bandung: CV. Informatika.
Jogianto, HM. 1993. Analisis \& Desain Sistem Informasi. Yogyakarta: Andi Offset.

Kadir A. 2002. Dasar Pemrograman Web Dinamis Menggunakan PHP. Yogyakarta: ANDI.

Kadir A. 2002. Penuntun Praktis Belajar $S Q L$. Yogyakarta: ANDI.

Kristanto H. 1994. Konsep dan Perancangan Database. Yogyakarta: ANDI.

Kurniawan, Dios. 1997. HTML 3 Untuk Publikasi di Internet. Yogyakarta: BPFE.

Llia Alshanetsky. 2005. php|architect's Guide to Security. Canada: Marco Tabini \& Associates, Inc.

Luke Welling \& Laura Thomson. 2001. PHP and MYSQL Web Development. USA: Sams Publishing.

Mance E Harmon, Stephanie S.Harmon, Reinforcement Learning: A Tutorial, 1996.

Netscape . 1999 . Client-Side JavaScript Guide . Netscape Communications Corporation.

Prasetyo, D. 2003. Tip Trik Kolaborasi PHP \& MySQL untuk membuat Web Database yang terakhir. Jakarta: PT Elex Media Komputindo.

Purbo, Onno W. 2002. Teknologi e-learning Berbasis PHP dan MySQL: Merencanakan dan Mengimplementasikan Sistem elearning. Jakarta: Gramedia.

Romi Satrio Wahono. 2005. Pengantar elearning dan pengembannya. http://www.ilmukomputer.com diakses tanggal: 8 Agustus 2007.

Sagala S. 2005. Konsep dan Makna Pembelajaran. Bandung: CV. Alfabeta.

Sidik B. 2002. Pemrograman Web dengan PHP. Bandung: CV. Informatika.

Wibawa, Nick Natha. 2006. Peran Teknologi Informasi dan Informasi dalam Pendidikan.

http://www.pasaman.go.id/?pilih=lihat \&id=322 . diakses tanggal: 8 Agustus 2007.

Jurnal Sains dan Teknologi| 33 
Yang Fan, Han Peng, Shen Ruimin, and $\mathrm{Hu}$ Zuwei. A Novel Resource Recommendation System Based on Connecting to Similar E-Learners. ICWI. 2005 